\title{
HUBUNGAN ANTARA PENGETAHUAN TENTANG KESEHATAN REPRODUKSI REMAJA DENGAN SIKAP SEKS PRANIKAH PADA SISWA KELAS XI DI SMA TAMAN MULAI TAHUN 2017
}

\section{Megalina Limoy ${ }^{1}$, Yovan Hendrik ${ }^{2}$}

\author{
Akademi Kebidanan Panca Bhakti Pontianak
}

Email korespondensi: akbidpbpontianak@gmail.com

\begin{abstract}
Abstrak
Remaja di Indonesia telah terbukti mulai melakukan hubungan seks pada usia muda. Berdasarkan penelitian di berbagai kota besar di Indonesia, sekitar 20-30\% mengaku pernah melakukan hubungan seks bebas diluar nikah. Tujuan penelitian ini adalah untuk mengetahui hubungan antara pengetahuan tentang kesehatan reproduksi remaja dengan sikap seks pranikah pada siswa kelas XI di SMA Taman Mulia tahun 2017. Penelitian ini menggunakan desain penelitian deskriptif korelasi dengan pendekatan cross sectional, jumlah sampel 53 orang dengan menggunakan purposive sampling dan alat penelitian dengan kuesioner. Analisis data dilakukan secara univariat dan analisis bivariat menggunakan uji Chi square. Dari hasil analisis univariat menunjukkan bahwa 39 responden (73,6\%) berpengetahuan baik, dan 3 responden $(5,7 \%)$ berpengetahuan kurang, sedangkan 31 responden $(58,5 \%)$ memiliki sikap mendukung dan 22 responden $(41,5 \%)$ memiliki sikap tidak mendukung. Hasil analisis bivariat didapatkan bahwa $\mathrm{p}=0,606>=0,05$ sehingga Ho diterima dan Ha ditolak, maka tidak ada hubungan antara pengetahuan tentang kesehatan reproduksi remaja dengan sikap seks pranikah pada siswa kelas XI di SMA Taman Mulia tahun 2017. SMA Taman Mulia diharapkan mampu memberikan pelajaran tentang kesehatan reproduksi remaja dan pendidikan seks pranikah sehingga mampu menambah pengetahuan siswa-siswi tentang kesehatan reproduksi remaja dan terjadi perubahan sikap yang baik bagi individu remaja itu sendiri dalam menyikapi sikap seks pranikah.
\end{abstract}

Kata Kunci: Pengetahuan, Sikap, Kesehatan Reproduksi Remaja, Seks Pranikah

\section{Pendahuluan}

\section{Menurut World Health Organization}

(WHO) kesehatan reproduksi adalah keadaan kesejahteraan fisik, mental, dan sosial yang utuh, bukan hanya bebas dari penyakit atau kecacatan dalam segala aspek yang berhubungan dengan sistem reproduksi, fungsi, serta prosesnya (Romauli, 2012). Menurut Badan Koordinasi Keluarga Berencana Nasional (BKKBN-UNICEF) dalam Marmi (2013), Kesehatan Reproduksi Remaja (KRR) secara umum didefinisikan sebagai kondisi sehat dari sistem, fungsi, dan proses alat reproduksi yang dimiliki oleh remaja, yaitu laki-laki dan perempuan usia 10-24 tahun.

Perilaku seksual adalah segala tingkah laku yang didorong oleh hasrat seksual, mulai

\footnotetext{
${ }^{1}$ Dosen Akademi Kebidanan Panca Bhakti Pontianak

${ }^{2}$ Dosen Akademi Kebidanan Panca Bhakti Pontianak
}

dari perasaan tertarik hingga tingkah laku berkencan, bercumbu, dan senggama. Objek seksual dapat berupa orang, baik sejenis maupun lawan jenis, orang dalam khayalan atau diri sendiri (Purwoastuti, 2015). Hasil Survei Kesehatan Reproduksi Remaja Indonesia (SKRRI) tahun 2011, remaja mengaku mempunyai teman yang pernah melakukan hubungan seksual pranikah usia 14-19 tahun (perempuan 34,7\%, laki-laki 30,9\%), usia 20-24 tahun (perempuan 48,6\%, laki-laki 46,5\%). Dengan responden remaja berusia antara 15-24 tahun menunjukkan bahwa sebanyak $1 \%$ remaja perempuan dan $6 \%$ remaja laki-laki menyatakan pernah melakukan hubungan seksual pranikah. 
Data dan Riset Kesehatan Dasar (RISKESDAS) tahun 2010 ditemukan jumlah remaja (laki-laki dan perempuan) 63.048 dengan status belum menikah $86,7 \%$ menjawab pernah melakukan hubungan seksual, laki-laki $3,0 \%$ dan perempuan $1,1 \%$. Usia menikah: umur 10-14 tahun 4,8\% dan usia 15-19 tahun 41,9\% (Kementerian Kesehatan RI, 2010). Data Survei Demografi dan Kesehatan Indonesia (SDKI) tahun 2012 pada laporan pendahuluan kesehatan reproduksi remaja tercatat wanita umur 15-19 tahun yang pernah melakukan hubungan seksual yaitu sebesar $0,7 \%$, umur 2024 tahun sebesar $1,8 \%$ sedangkan pria umur 1519 tahun yang pernah melakukan hubungan seksual yaitu sebesar 4,5\% dan umur 20-24 sebesar 14,6\% (Kementerian Kesehatan RI, 2012).

Hasil penelitian yang dilakukan Persatuan Keluarga Berencana Indonesia/PKBI (2010) di kota Palembang, Kupang, Tasikmalaya, Cirebon, dan Singkawang remaja yang sudah melakukan hubungan seksual di luar nikah sudah cukup tinggi yaitu 9,1\% dan $85 \%$ hubungan seks pertama pada usia $13-15$ tahun yang dilakukan dengan pacar di rumah mereka. Hasil penelitian yang dilakukan oleh Suwarni Linda pada tahun 2015 dengan jumlah sampel adalah 300 remaja SMP dan SMA yang ada di 6 kecamatan Kota Pontianak. Hasil penelitian ini menunjukkan inisiasi seks remaja diawali dengan pegangan tangan (82,7\%), berpelukan $(60,7 \%)$, cium pipi $(66 \%)$, meraba daerah sensitif (19,3\%), seks oral (7\%), seks anal (4\%), dan intercourse $(14,7 \%)$.

Hasil penelitian yang dilakukan oleh Mita Ardiyanti dengan judul hubungan antara pengetahuan kesehatan reproduksi dengan perilaku seksual pranikah remaja SMAN 1 Imogiri pada tahun 2013 menunjukkan bahwa pengetahuan kesehatan reproduksi termasuk dalam kategori sangat tinggi sebanyak $4 \%$, diikuti kategori tinggi sebanyak $88 \%$, sedangkan sisanya sebanyak $8 \%$ dalam kategori sedang dan sebanyak 79\% siswa berperilaku seksual termasuk dalam kategori rendah.

Hasil penelitian dari Ikatan Peminat Demografi Indonesia Provinsi Kalimantan Barat bahwa dikota Pontianak perilaku seks pranikah terhadap 94 siswa-siswi kelas 2 di SMK Kecamatan Pontianak Timur pada tahun 2012 mencatat $51,1 \%$ diantaranya pernah melakukan seks pranikah. Menurut anggota Ipadi Provinsi Kalbar M Taufik SKM, MKM, remaja di Provinsi itu sudah mengalami pendewasaan sebelum waktunya.

Di Kabupaten Kubu Raya, penelitian tentang kehamilan yang tidak diinginkan terhadap 88 calon pengantin di wilayah kerja Puskesmas Sungai Kakap pada tahun 2014 mencapai $63,6 \%$ positif hamil. Data kehamilan yang tidak diinginkan di kalangan pengantin remaja umumnya terjadi akibat kurang baiknya pengetahuan masa subur calon pengantin, dan juga keluarga yang tidak mendukung pendewasaan usia perkawinan. Solusinya adalah dengan pendidikan kesehatan reproduksi sejak usia dini.

Aktivitas seksual menempatkan remaja pada tantangan risiko terhadap berbagai masalah kesehatan reproduksi. Setiap tahun kira-kira 15 juta remaja berusia 15-19 tahun melahirkan, 4 juta melakukan aborsi, dan hampir 100 juta terinfeksi penyakit menular 
seksual (PMS) yang dapat disembuhkan. Secara global, 40\% dari semua kasus infeksi HIV terjadi pada kaum muda yang berusia 15-24 tahun. Perkiraan terakhir adalah setiap hari ada 7.000 remaja terinfeksi HIV (Purwoastuti, 2015).

Pencapaian yang masih dibawah target terlihat dari tidak tercapainya target indikator kinerja Standar Pelayanan Minimal Bidang Kesehatan Tahun 2015. Salah satu indikator capaian yang perlu mendapat perhatian karena persentase pencapaian masih berada dibawah target adalah cakupan pelayanan kesehatan remaja mencapai sebesar $65,76 \%$ pada tahun 2015 sedangkan target nasional sebesar $75 \%$ (Dinkes Kal-Bar, 2015).

Berdasarkan studi pendahuluan yang dilakukan peneliti di sekolah SMA Taman Mulia bahwa jumlah kelas XI IPA dan IPS berjumlah 111 orang, laki-laki 56 orang dan perempuan 55 orang. Dan hasil wawancara pada 19 orang siswa-siswi, laki-laki 11 orang dan perempuan 8 orang. Hasil wawancara didapatkan bahwa sebagian 53\% (10 orang) memiliki pengetahuan yang kurang tentang kesehatan reproduksi remaja, sebagian besar 74\% (14 orang) memiliki pengetahuan yang kurang tentang perilaku seks pranikah, sebagian 53\% (10 orang) siswa laki-laki sudah merokok dan hampir seluruh 95\% (18 orang) siswa-siswi sudah dan pernah berpacaran.

Menurut Data Sekolah SMA Taman Mulia Juli 2016 hingga Februari 2017 terdapat siswa-siswi yang putus sekolah dikarenakan beberapa penyebab diantaranya: Hamil diluar nikah sebanyak 4 orang $(1,23 \%)$, faktor ekonomi sebanyak 3 orang $(0,92 \%)$ dan faktor internal atau tidak ada kemauan dari siswa untuk bersekolah sebanyak 1 orang $(0,30 \%)$. Selain itu penyuluhan tentang kesehatan reproduksi remaja atau sejenisnya belum pernah dilakukan di SMA Taman Mulia Kecamatan Sungai Raya Kabupaten Kubu Raya.

\section{Metode}

Penelitian ini menggunakan jenis penelitian deskriptif korelasional dengan pendekatan cross sectional. Penelitian dilaksanakan pada bulan Februari hingga Mei 2017 di SMA Taman Mulia Kabupaten Kubu Raya. Populasi penelitian yaitu siswa kelas XI IPA dan XI IPA sebanyak 111 orang. Peneliti menggunakan $10 \%$ pupulai sebagai sampel sebanyak 53 orang. Pengumpulan data menggunakan kuesioner kemudian diolah dan dianalisis menggunakan analisis univariate serta analisis bivariate menggunakan uji chi square.

\section{Hasil dan Pembahasan}

Tabel 1. Karakteristik Responden

\begin{tabular}{lcc}
\hline \multicolumn{1}{c}{ Karakteristik } & $\mathrm{n}$ & $\%$ \\
\hline Pengetahuan & 39 & 73,6 \\
$\quad$ Baik & 11 & 20,7 \\
Cukup & 3 & 5,7 \\
$\quad$ Kurang & & \\
Sikap & 31 & 58,5 \\
$\quad$ Mendukung & 22 & 41,5 \\
$\quad$ Tidak Mendukung &
\end{tabular}


Berdasarkan tabel 1 diketahui bahwa sebagian besar dari responden yaitu 39 responden $(73,6 \%)$ memiliki pengetahuan baik dan sangat sedikit dari responden yaitu 3 responden $(5,7 \%)$ memiliki pengetahuan kurang. Berdasarkan tabel 1 diketahui bahwa sebagian dari responden yaitu 31 responden $(58,5 \%)$ memiliki sikap mendukung.

Tabel 2. Hubungan Antara Pengetahuan Tentang Kesehatan Reproduksi Remaja dengan Sikap Seks Pranikah

\begin{tabular}{|c|c|c|c|c|c|c|c|c|}
\hline \multirow{4}{*}{ Variabel } & \multicolumn{4}{|c|}{ Sikap } & \multirow{2}{*}{\multicolumn{2}{|c|}{ Total }} & \multirow[b]{2}{*}{ OR } & \multirow{4}{*}{ P Value } \\
\hline & \multirow{2}{*}{\multicolumn{2}{|c|}{ Mendukung }} & \multicolumn{2}{|c|}{ Tidak } & & & & \\
\hline & & & \multicolumn{2}{|c|}{ Mendukung } & & & \multirow{2}{*}{$95 \%$} & \\
\hline & $\sum$ & $\%$ & $\sum$ & $\%$ & $\sum$ & $\%$ & & \\
\hline \multirow{3}{*}{ Pengetahuan } & 1 & 33,3 & 2 & 66,7 & 3 & 100 & \multirow{3}{*}{0,189} & \multirow{3}{*}{0,606} \\
\hline & 6 & 54,5 & 5 & 45,5 & 11 & 100 & & \\
\hline & 24 & 61,5 & 15 & 38,5 & 39 & 100 & & \\
\hline
\end{tabular}

Berdasarkan hasil penelitian terhadap 53 responden yaitu siswa kelas XI IPA dan IPS tentang kesehatan reproduksi bahwa sebagian besar dari responden yaitu 39 responden (73,6\%) memiliki pengetahuan baik, sebagian kecil dari responden yaitu 11 responden (20,7\%) memiliki pengetahuan cukup dan sangat sedikit dari responden yaitu 3 responden $(5,7 \%)$ memiliki pengetahuan kurang.

Berdasarkan teori Notoatmodjo (2010), pengetahuan adalah hasil penginderaan manusia, atau hasil tahu seseorang terhadap objek melalui indera yang dimilikinya (mata, hidung, telinga dan sebagainya). Sebagian besar pengetahuan seseorang diperoleh melalui indera pendengaran (telinga), dan indera penglihatan (mata).

Pengetahuan remaja tentang kesehatan reproduksi dan perilaku seksual remaja di SMA Taman mulia banyak diperoleh dari sumbersumber nonformal yang memungkinkan terjadinya kesalahpahaman remaja tentang perilaku seks pranikah. Sumber- sumber tersebut antara lain dari teman sebaya, media massa, dan sumber-sumber lainya. Hal ini disebabkan remaja merasa lebih leluasa berbicara tentang perilaku seksual dengan teman-teman sebaya daripada orang tua dan mudahnya memperoleh sumber-sumber media massa yang berisikan perilaku seks.

Dampak dari kurangnya sumber formal yang diperoleh remaja menyebabkan remaja memiliki persepsi yang salah tentang perilaku seks pranikah. Persepsi tersebut umumnya adalah anggapan bahwa perilaku seks pranikah adalah ketika mereka melakukan kegiatan penetrasi (senggama) dengan lawan jenis, sedangkan perilaku saling berciuman, meraba lawan jenis, hingga petting belum termasuk perilaku seksual pranikah, karena tidak menimbulkan kehamilan.

$$
\text { Menurut Mubarak }
$$

mengemukakan bahwa faktor yang mempengaruhi tingkat pengetahuan ada tiga yaitu: Pendidikan, semakin tinggi pendidikan seseorang semakin mudah menerima informasi sehingga semakin banyak pula pengetahuan yang dimiliki. Pekerjaan, pekerjaan bukanlah 
sumber kesenangan, tetapi lebih banyak merupakan cara mencari nafkah yang membosankan, berulang dan banyak tantangan. Umur, umur individu yang terhitung mulai saat dilahirkan sampai berulang tahun.

Penelitian ini sesuai dengan penelitian yang dilakukan oleh Pratama (2013) dengan judul hubungan antara pengetahuan tentang kesehatan reproduksi dengan sikap seksual pranikah remaja menunjukan bahwa sebagian besar responden memiliki tingkat pengetahuan rendah yaitu sebanyak 55 responden $(63 \%)$ dan pengetahuan tinggi sebanyak 33 responden $(38 \%)$.

Berdasarkan hasil kuesioner dapat diketahui bahwa siswa kelas XI di SMA Taman Mulia memiliki pengetahuan yang baik tentang kesehatan reproduksi remaja. Dalam teori Notoatmodjo (2007), dikatakan bahwa seseorang akan baik apabila mendapatkan informasi yang baik juga misalnya pengetahuan tentang kesehatan reproduksi remaja merupakan hal yang penting untuk diketahui. Dari hasil penelitian terhadap 53 responden yaitu siswa kelas XI IPA dan IPS tentang sikap seks pranikah bahwa sebagian dari responden yaitu 31 responden $(58,5 \%)$ memiliki sikap mendukung seks pranikah sedangkan sebagian dari responden yaitu 22 responden $(41,5 \%)$ memiliki sikap tidak mendukung seks pranikah.

Berdasarkan teori Notoatmodjo (2010) bahwa Sikap adalah merupakan reaksi atau respon seseorang yang masih tertutup terhadap stimulasi atau objek. Manifestasi sikap tidak dapat langsung dilihat, tetapi hanya dapat ditafsirkan terlebih dahulu dari perilaku yang tertutup. Sikap remaja di SMA Taman Mulia yaitu sebagian mendukung seks pranikah, artinya remaja memiliki sikap yang positif tentang seks pranikah. Hal ini sesuai dengan teori Azwar (2009), bahwa faktor-faktor yang mempengaruhi pembentukan sikap adalah pengalaman pribadi, kebudayaan, orang lain yang dianggap penting, media massa, institusi atau lembaga pendidikan dan lembaga agama, serta faktor emosi dalam diri individu.

Penelitian ini sesuai dengan penelitian yang dilakukan oleh Pratama (2013) dengan judul hubungan antara pengetahuan tentang kesehatan reproduksi dengan sikap seksual pranikah remaja menunjukkan bahwa sebagian besar responden menolak yaitu sebanyak 46 responden $(52 \%)$ dan sisanya 42 responden (48\%) bersikap mendukung. Berdasarkan hasil penelitian didapatkan bahwa $\mathrm{p}=0,606>=0,05$ maka dapat ditarik kesimpulan bahwa Ho diterima dan Ha ditolak, dengan demikian dapat dikatakan bahwa tidak ada hubungan antara pengetahuan siswa tentang kesehatan reproduksi remaja dengan sikap seks pranikah di SMA Taman Mulia Kubu Raya.

Walaupun secara statistik tidak ada hubungan, namun data memperlihatkan bahwa pengetahuan yang baik mempengaruhi sikap yang baik pula, terlihat dari jumlah responden yang berpengetahuan baik dengan sikap tidak mendukung yaitu 15 responden $(38,5 \%)$ dibandingkan dengan responden yang berpengetahuan kurang dengan sikap mendukung yaitu 1 responden $(33,3 \%)$.

Kondisi ini disebabkan adanya faktor lain yang mempengaruhi sikap seks pranikah, misalnya teman sebaya dan media massa menyebabkan timbulnya sikap mendukung 
perilaku seksual pranikah. Pengalaman dari teman sebaya yang pernah melakukan perilaku seks pranikah dan ternyata menurut mereka tidak menimbulkan dampak negatif akan menerima sikap mereka untuk mendukung perilaku seks pranikah. Hal ini sebagaimana dikemukakan oleh Thorton \& Camburn (Pratama, 2013) yang mengemukakan bahwa faktor-faktor yang berhubungan dengan sikap terhadap seks pranikah remaja adalah lingkungan tempat tinggal, kawan, keluarga, dan komunitas.

Hasil penelitian yang sesuai adalah penelitian Siswanto, dkk (2006) tentang hubungan antara tingkat pengetahuan HIV/AIDS dengan perilaku seksual pada remaja di Indonesia. Penelitian ini menyimpulkan bahwa tidak ada hubungan antara tingkat pengetahuan HIV/AIDS dengan perilaku seksual pada remaja berumur 15-24 tahun yang belum menikah di Indonesia. Dan hasil penelitian sesuai dengan penelitian dilakukan oleh Firza (2011) tentang hubungan antara pengetahuan remaja tentang pendidikan seks dengan perilaku seksual pranikah pada remaja. Penelitian ini menyimpulkan bahwa tidak ada hubungan yang signifikan dari pengetahuan remaja tentang pendidikan seks dengan perilaku seksual pranikah pada remaja.

Hasil penelitian ini ternyata tidak sesuai dengan penelitian yang dilakukan oleh Fadila (2010) tentang hubungan pengetahuan dengan sikap seksual pranikah pada remaja. Penelitian ini menunjukkan bahwa ada hubungan yang positif antara pengetahuan dan sikap tentang seksual pranikah pada remaja kelas X di SMAN
3 Surakarta, yaitu semakin baik pengetahuan remaja, maka sikapnya semakin positif.

Dalam teori Soetjiningsih (2007), faktor lain yang mempengaruhi perilaku seks pranikah remaja adalah faktor lingkungan seperti, paparan media massa, baik cetak (koran, majalah, buku-buku porno) maupun elektronik (TV, VCD, Internet), mempunyai pengaruh secara langsung maupun tidak langsung pada remaja untuk melakukan hubungan seks pranikah.

Pendidikan kesehatan reproduksi bagi siswa khususnya seks pranikah sebaiknya diberikan baik dilingkungan formal maupun informal seperti sekolah, agar mereka mengetahui dan memahami tentang kesehatan reproduksinya dan akibat-akibat dari seks pranikah.

Berdasarkan hal tersebut diatas, walaupun tidak ada terdapat hubungan antara pengetahuan tentang kesehatan reproduksi remaja dengan sikap seks pranikah, tetapi masih ditemukan siswa yang memiliki pengetahuan yang kurang dan juga banyak sikap mendukung sehingga diharapkan siswa agar selalu menambah pengetahuan dan wawasan tentang kesehatan reproduksi remaja dan seks pranikah dengan berbagai macam sumber misalnya media massa, media elektronik, buku, petugas kesehatan, kerabat dekat dan sebagainya, sehingga apabila siswa mempunyai pengetahuan tentang kesehatan reproduksi remaja maka dalam menyikapi hal-hal yang berkaitan dengan seks pranikah tersebut siswa akan lebih mengetahui dan memahami bagaimana sebab akibat seks pranikah tersebut. 


\section{Kesimpulan}

Berdasarkan hasil penelitian yang telah dilakukan, maka dapat disimpulkan bahwa tidak ada hubungan antara pengetahuan siswa tentang kesehatan reproduksi remaja dengan sikap siswa terhadap perilaku seks pranikah. SMA Taman Mulia diharapkan mampu memberikan pelajaran tentang kesehatan reproduksi remaja dan pendidikan seks pranikah sehingga mampu menambah pengetahuan siswa-siswi tentang kesehatan reproduksi remaja dan terjadi perubahan sikap yang baik bagi individu remaja itu sendiri dalam menyikapi sikap seks pranikah.

\section{Daftar Pustaka}

Ardiyanti, Mita. 2013. Hubungan Antara Pengetahuan Kesehatan Reproduksi Dengan Perilaku Seksual Remaja SMAN 1 Imogiri. Diambil dari : Http://psikologi.ustjogja.ac.id, diakses 19-2-2017, 11.47 WIB

Arikunto, Suharsimi. 2006. Prosedur Penelitian Suatu pendekatan Praktik Edisi Revisi VI. Rineka Cipta: Jakarta

Asna, Khodijatul. 2011. Hubungan Antara Pengetahuan dan Sikap Terhadap Kesehatan Reproduksi Dengan Perilaku Seksual Pranikah Di SMAN 14 Kota Semarang. Diambil dari: Http://lib.unnes.ac.id, diakses 19-2-2017, 11.44 WIB

Azwar, S. 2009. Sikap Manusia: Teori Dan Pengukurannya. Pustaka Pelajar: Yogyakarta

Bungin, B. 2009. Erotika Media Massa. Muhammadiyah University Press: Surakarta

Data Sekolah SMA Taman Mulia Kubu Raya. 2016

Engga, P. 2016. Angka Kejadian Seks Pranikah Di Indonesia. Diambil dari:
Http://repository.usu.ac.id, diakses 19-22017, 11.57 WIB

Fadila. 2010. Hubungan Antara Pengetahuan Dengan Sikap Seksual Pranikah Remaja di SMA 3 Surakarta. Diambil dari : Http://eprints.uns.ac.id, diakses 03-52017, 19.40 WIB

Firza, Febrian. 2011. Hubungan Pengetahuan Remaja Tentang Pendidikan Seks Dengan Perilaku Seks Pranikah. Diambil Dari: Http://Repository.uin-suska.ac.id, di akses 03-5-2017 , 20.30 WIB

Hidayat, Aziz Alimul. 2014. Metode Penelitian Kebidanan dan Teknik Analisis Data Contoh Aplikasi Studi Kasus. Salemba Medika: Jakarta

Irianto, K. 2014. Panduan Lengkap Biologi Reproduksi Manusia. CV Alfabeta: Bandung

Kusmiran, Eni. 2012. Kesehatan Reproduksi Remaja dan Wanita. Salemba Medika: Jakarta

Machfoed, Ircham. 2010. Metodologi Penelitian. Fitramaya: Yogyakarta

Manuaba, IBG. 2009. Memahami Kesehatan Reproduksi Wanita. EGC: Jakarta

Marmi. 2013. Kesehatan Reproduksi. Pustaka Pelajar: Yogyakarta

Maulana, Heri D.J. 2013. Promosi kesehatan. EGC: Jakarta

Mubarak, Wahit Iqbal. 2007. Promosi Kesehatan. Graha Ilmu: Yogyakarta

Notoatmodjo, Soekidjo. 2007. Promosi Kesehatan dan Ilmu Perilaku. Rineka Cipta: Jakarta

2010a. Metodologi penelitian kesehatan. Rineka Cipta: Jakarta

2010b. Promosi Kesehatan teori dan Aplikasi. Rineka Cipta: Jakarta

Nugroho, Taufan. 2010. Kesehatan Wanita, Gender dan Permasalahannya. Nuha Medika: Yogyakarta 
Pinem, Saroha. 2009. Kesehatan Reproduksi Dan Kontrasepsi. CV Trans Info Media: Jakarta

Prawirohardjo, Sarwono. 2010. Ilmu kebidanan. PT Bina Pustaka Prawirohardjo: Jakarta

Profil Kesehatan Kota Pontianak. 2015. Situasi Derajat Kesehatan

Profil SMA Taman Mulia Kubu Raya. 2017 Purwoastuti, Endang. 2015. Panduan Materi Kesehatan Reproduksi dan Keluarga Berencana. Pustaka baru press: Yogyakarta

Rahyani, Ni Komang Y. 2013. Kesehatan Reproduksi Buku Ajar Bidan. EGC: Jakarta

Riyanto, Agus. 2011. Aplikasi Metodologi Penelitian Kesehatan. Nuha Medika: Yogyakarta

Rohan, H. 2013. Kesehatan Reproduksi. Nuha Medika: Yogyakarta

Romauli, Suryati. 2012. Kesehatan Reproduksi Buat Mahasiswi Kebidanan. Nuha Medika: Yogyakarta

Sarwono Wirawan Sarlito. 2006. Psikologi Remaja. Raja Grafindo Persada: Jakarta

Sastroasmoro, Sudigdo. 2011. Dasar-Dasar Metodologi Penelitian Klinis. CV sagung Seto: Jakarta

Setiawan, Ari. 2011. Metodologi Penelitian Kebidanan DIII, DIV, S1, dan S2. Nuha Medika: Yogyakarta

Siswanto, dkk. 2014. Metodologi Penelitian Kesehatan dan Kedokteran. Bursa Ilmu: Yogyakarta

Siswanto. 2006. Hubungan Antara Tingkat Pengetahuan HIV/AIDS Dengan Perilaku Seksual Pada Remaja Di Indonesia. Skripsi Fakultas Psikologi UI: Jakarta

Soetjiningsih. 2007. Tumbuh Kembang Remaja dan Permasalahannya. Sagung Seto: Jakarta
Sugiyono. 2010. Statistika untuk Penelitian. CV Alfabeta: Bandung

Suwarni, Linda. 2015. Inisiasi Seks Pranikah Remaja Dan Faktor Yang Mempengaruhi. Diambil dari: Http://journal.unnes.ac.id, diakses 19-22017, 11.45 WIB

Widyastuti, Yani. 2009. Kesehatan Reproduksi. Fitramaya: Yogyakarta

Windiyati. 2017. Buku Pedoman Penyusunan Karya Tulis Ilmiah: Pontianak

Yoga Pratama. 2013. Hubungan Antara Pengetahuan Tentang Kesehatan Reproduksi Dengan Sikap Seksual Pranikah Remaja Di Kelurahan Danguran Kabupaten Klaten. Di ambil dari: Http://eprints.ums.ac.id, diakses tanggal 03-5-2017, jam 19:31 WIB 